\title{
Effect of Trust, Satisfaction, and Commitment on Customer Loyalty At the Alfamart Retail in Surabaya, East Java - Indonesia
}

\author{
J.E. Sutanto \\ Graduate School, Universitas Ciputra of Surabaya- \\ Indonesia,
}

\author{
S. Pantja Djati \\ Doctoral Programs, Mercu Buana University \\ of Jakarta-Indonesia
}

\begin{abstract}
The research objective has to determine the Effect of Trust, Satisfaction and Commitment on Customer Loyalty in the Alfamart Retail at Surabaya, East Java, Indonesia. Hopefully will be able to the AEC 2015 retail business in Indonesia's is expected to be better.
\end{abstract}

Modern retail is essentially a development of traditional retail. This retail formats emerge and evolve as economic development, technology, and lifestyle that makes people demand more convenience in shopping. The population used all of Alfamart retail at Surabaya there are 234 units of minimarket and sample of 70 units. While for the processing of the data was analyzed with multiple linear regressions aided by using SPSS version 20.

Results of research was found that the partial and simultaneously variables $X 1, X 2$, and $X 3$ have a significant effect to the variable $Y$.

\section{KEYWORDS: Trust, Satisfaction, Commitment,} Customer Loyalty. Alfamart Retail

\section{INTRODUCTION}

Retailing consists of all activities involved in selling services and also goods to consumers for all of their family and personal or household use. Retailing is one of the largest sectors in the global economy and is going through an evolutionary stage in Indonesia. From now on customer satisfaction gained new attention in a shift paradigm from transaction marketing to relationship marketing (Bricci et al., 2016) and in numerous publications satisfaction was presented as a necessary premise for customer retention and also thus moved to the forefront of approaches to relationship marketing for researchers (Thurau and Klee, 1997).

Foregoing studies of satisfaction (Oliver, 1981; Churchill and Suprenant, 1982), present models of customer satisfaction among them those surveyed Fornell et al., (1996) to propose the application of Satisfaction. The link between satisfaction and long-term retention of customers is typically formulated by marketing professionals and academics in a very categorical way, and therefore as a starting point rather than central question of analysis (Bricci et al., 2016).
Retail business in Indonesia is the sale of goods at retail outlets in various types such as kiosks, markets, department stores, boutiques and others, which is generally to be employed directly by the buyer concerned. The development of studies of trust in organizational settings has been viewed as an emerging requirement and resulting transformations of labor. Beside that it is also recognized that the existence of trust between individuals, in teams in organizations is a necessary mechanism for the work to be done more an efficient.

Trust is the foundation of the business. A business transaction between two parties or more would occur if each mutual trust. Trust is not just to be recognized by other parties / business partners, but must built starting from the beginning and can be proved (Gefen, 2002; Rousseau et al. 1998; Morgan dan Hunt,1994)

The rapid growth of retail business in Indonesia, the largest retail company in Indonesia PT. Sumber Alfaria Trijaya sees great market potential and is committed to developing the retail business to the digital market. According to San Martin et al. (2004) that commitment is as the central in relationship marketing in the way the companies and the customers' engagement in a relationship. The commitment has been widely recognized as an integral part of any business relationship. Meyer and Allen (1997) commitment is mainly focused on an attitude of open questions that guide an individual or behavioral intentions. Herscovitch and Meyer (2002) define commitment as a force that binds an individual to a course of action relevant to one or more targets.

According to Ganiyu et al., (2012) customer loyalty can seem elusive and also magical to those trying to obtain it. However, there are a lot of strong reasons for businesses to pursue customer loyalty as an objective of strategic. Customers are expensive to acquire; keeping them loyal allows you to amortize of acquisition costs. In general for loyal customers are often willing to pay of premium prices. Customer loyalty depends on committed teams, employees and suppliers and owners committed to building a company of enduring success, i.e., a network where all participants are key pieces for your support. The author states that loyalty has become a bargaining chip between customer and company (Bricci et al., 2016). The retail industry continues 
to grow rapidly, not only in Indonesia, but also in Asia. The era of modern retail towards the Asean Economic Community (AEC) in 2015 is expected to grow faster. It was supported by many foreign companies will invest in Indonesia. PT. Alfaria Trijaya Tbk. presents an exclusive product that is only sold in stores see Table 1 and projection as targets of outlet in 2017 based on Table 2.

Table 1. The Growth of Outlets (Units) In $2005-2008$

\begin{tabular}{|c|c|c|c|c|}
\hline Year & 2005 & 2006 & 2007 & 2008 \\
\hline $\begin{array}{c}\text { Minimarket } \\
\text { Growth }\end{array}$ & 1263 & 1763 & 2266 & 2750 \\
\hline
\end{tabular}

Source: AC Nielsen, SWA No. 06/XXV (2009)

Table 2. Projection of Outlets (Units) In $2009-2017$

\begin{tabular}{|c|c|c|c|c|c|c|c|c|c|}
\hline Year & 2009 & 2010 & 2011 & 2012 & 2013 & 2014 & 2015 & 2016 & 2017 \\
\hline $\begin{array}{c}\text { Minimarket } \\
\text { Growth }\end{array}$ & 3251 & 3748 & 4245 & 4741 & 5238 & 5734 & 6231 & 6730 & 7284 \\
\hline
\end{tabular}

Source: Forecasting based on Data in 2005 - 2008 (2017)

\section{LITERATURE REVIEW}

\section{Trust}

Trust is "one of the most critical factors in sellerconsumer relationship, and is an importance element defining the strength of the relationship". Trust is" essential to maintaining long-term relationships, and it is defined as a willingness to rely on an exchange partner in whom one has confidence" (Moorman et al., 1992). Trust" has to be considered as catalysts in a variety of transactions between sellers and buyers so that customer satisfaction can be realized as expected" (Yousafzai et al., 2003; Mukherjee and Nath, 2003; Reigelsberger et al., 2003; Murphy and Blessinger, 2003; Kim and Tadisina, 2003)

Trust is very important in conditions without boundaries where all consumers from various ethnic groups can interact with the Retail Alfamart according to expectations. Morhan and Hunt (1994), their trust "if one of the parties has confidence in the integrity and reliability of the other party or expressing confidence as willingness to reach others who have believed". Yau et al. (2000) trust is one of the dimensions that determine the extent to which the integrity and promise offered Alfamart can be perceived by consumers. Groonos (1997), "the focus ongoing relationship is assets such as customer trust, commitment and loyalty".

Patricia et al. (2007) states "that there is an influence of trust building behaviors (social interact ion, open communications, customer orientation) and service outcomes (technical, functional and economic quality) on trust formation". Trust is "shown to have a positive influence on key relational outcomes, commitment of loyalty and share of purchases". To support to the influence of trust on commitment of loyalty and expanded protection in an services setting. Kumar and Raju (2014) trust: "guarantees are a great way to increase the levels of trust between you and your customers, and give yourself a competitive advantage". A guarantee is "a kind of product insurance, protecting your customers' investments if their shopping experience turns out to be less than satisfactory".

According to Mayer et al. (1995) and Kim et al. (2003a) factors "that shape a person's belief over another", there are three, namely: (1) ability: competence, experience; institutional knowledge and ability in science. (2) benevolence: attention, empathy, confidence, and acceptance, and (3) integrity: fairness, fulfillment, loyalty, honestly, dependability and reliability.

\section{Satisfaction}

Satisfaction refers "to a positive state resulting from the appraisal of all attributes of customer working relationship with firm". Homburg and Rudolph (2001) said that "satisfaction as a relationship constructs describing how a supplier fills the expectations of a customer in the following areas: characteristics of the product, services, information related to product, complaints management, taking orders and interactions with internal staff". Besides that, "satisfaction appears as a concept highly integrated in the relationship". De Wulf et al. (2001) "consider the relationship satisfaction placed in affective theory". Anderson and Narus (1990 "defined as a consumer's affective state resulting from an overall appraisal of his or her relationship with a retailer". Customer satisfaction in "special of services has been defined as the degree to which service performance meets or exceeds the customer's expectations" (Kumar, 2012; Santouridis and Trivellas, 2010). Satisfaction as an evaluative judgment of a specific transaction resulting from perceived quality (Hui and Zheng, 2010).

Zeithami et al. (1996) customer satisfaction "is important to get long-term business success). To protect market profit, organizations need to overcome competitors through offering high quality products or services to ensure customer satisfaction" (Tsoukatos and Rand, 2006). Oliver (1980) "indicates that customer satisfaction requires full meeting customer expectations of products and services, when expectations are met, satisfaction results and not met expectations lead to dissatisfaction". "If performance matches or exceeds customer expectations for service, they are satisfied, but if not, they are not satisfied" (Munusamy et al., 2010). Several studies generally "define customer satisfaction and dissatisfaction as the customer's judgments concerning a business's success or failure in meeting expectations" (Kheng et al., 2010; Chidambaram, and Ramachandran, 2012). Lau et al. (2013) "that the attitude of customer satisfaction resulting from what customers believe should anticipation compared with the situation when and what they believe is not the perceived performance".

Based on most studies confirm "that there is a relationship between service quality and customer satisfaction". For example: (1) Caruana (2002) "found a positive relationship between service quality and customer satisfaction", and (2) Liniere, (2013) "also found that perceived service quality influences customer satisfaction", For this study "using five indicators for measurement of customer satisfaction namely: (1) tangibles, (2) reliability, 
(3) responsiveness, (4) empathy, and (5) assurance" (Parasuraman et al., 1991; Rangkuti, 2003).

\section{Commitment}

Commitment in "the buyer-seller relationship is prevalent in marketing and commitment has widely been acknowledged to be an integral part of any long-term business relationship" (Dwyer et al 1987; Anderson and Weitz 1992; Morgan and Hunt 1994). "Commitment to a relationship entails a desire to develop a stable relationship, a willingness to make short term sacrifices to maintain the relationship, and a confidence in the stability of the relationship" (Anderson and Weitz (1992). For example, Morgan and Hunt (1994) "define relationship commitment as "an exchange partner believing that an ongoing relationship with another is so important as to warrant maximum efforts".

According to Ibrahim and Najjar (2008), that relationships are built on the foundation of mutual commitment, and the commitment level has been found to be the strongest predictor of the voluntary decision to pursue a relationship". Du Plessis (2010), "more committed customers tend to form a positive overall impression of the total duration of the relationship, including different transactions, and these customers exhibit strong intentions to stay in the relationship". "For example special higher levels of commitment are expected with relationship success" (Cai and Wheale, 2004). Conclusion in that certain levels of "commitment are required to initiate the relationship, and as the relationship evolves, so does the existence of commitment". Davis et al.(2008); Evanshitzky and Plaassmann (2006) and Du Plessis (2010), "that dimension of commitment is then formed through (1) behavioral, (2) attitudinal and (3) affective influences". There are several indicators of employee commitment. Kaswara and Santoso (2008) "present three indicators used in the approach to determine indicators of employee commitment to the organization, namely: (1) affective commitment; (2) continuance commitment, and (3) normative commitment".

\section{Customer Loyalty}

A customer loyalty is defined as "the adherence of customers to a company but even if businesses make mistakes, loyal customers will not leave". According to Kincaid (2003) "defines loyalty of customer : (1) as a consumer behavior, (2) built on positive experience and (3) value, which leads to buying products, when that may not appear to be the most rational decision". Peppers and Rogers (2004), "the concept was later divided in to behaviouristic and non-behaviouristic indicators where the latter is more focused on the underlying causes of loyalty of customer and attitudes of consumers".

Schweizer (2008) "in the investigation to the loyalty of customer, it is valid to explore two fields: firstly the behavior of consumers and second their intentions". Based on Stone et al., (2000) "that customer loyalty is also dependent on a number of customer related factors, and for example: how customers perceive the business rather than what the business really does". For given all these benefits, it's only natural that businesses should turn to a diverse range of efforts to develop loyalty of customer.

For "each company seems to have a different formula for making that loyalty of customers. Than initiatives include: (1) creation of valuable customer experiences, (2) creation of resonant brand, (3) proactive marketing initiatives, (4) control of quality processes, and (5) customer relationship management" (Ganiyu et al., 2012)

\section{RESEARCH METHODS}

\section{Population and Sample}

population is all the elements that usually a person, object or event of interest to be an object of research. Total population $=234$ units. While "the sample is a part of the population that can represent the characteristic of the population used in the research" (Koncoro, 2013: 118) and total sample $=70$ units.

\section{Test of Validity}

"Prior of research instrument used for data collection, it is necessary to test in advance to ensure that the instrument is declared invalid". "Test the validity of these instruments is done by using the pearson product moment, which is to examine the correlation of each score with a total score in order to determine the valid of each question". Such "an instrument is declared eligible if significance $<0.05$, then the instrument is declared valid" (Priyanto, 2013: 19)

\section{Test of Reliability}

Reliability "is the consistency instrument research, so reliabilities is a measure of consistency in the respondent's answer related questions". "A research instrument said to be reliable if the value of Cronbach Alpha > 0:06 (Ghozali, 2009: 45), and also that Cronbach Alpha if item Deleted < Cronbach Alpha” (Nugroho, 2011)

\section{Research Framework}

The following research framework as shown in Figure 2 , based on research purposes, literature and hypothesis.

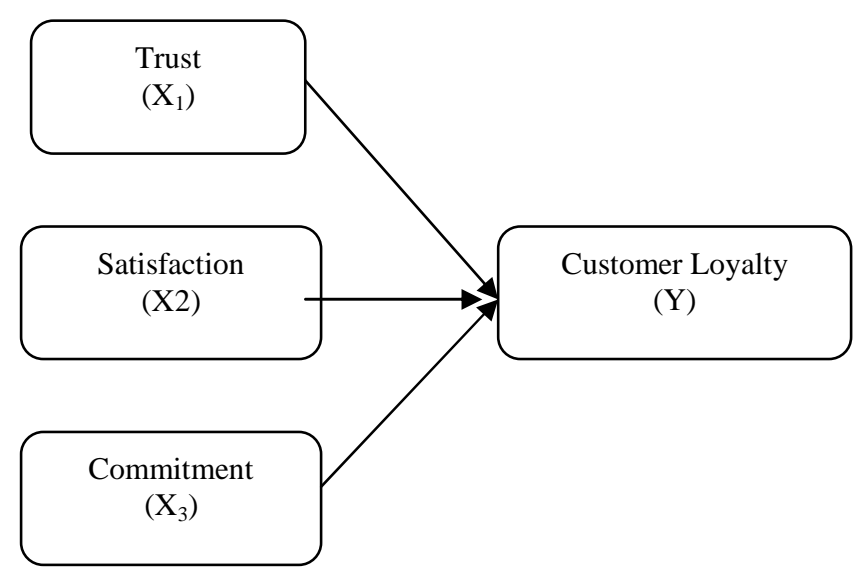

Figure 2. Research Framework 


\section{IV.RESULT AND DISCUSSION}

Based on with the purpose of research for data analysis will be performed using multiple linier regression equation with SPSS (Santoso, 2012). Which "multiple linier regression analysis model in this research is the variable $\mathrm{Y}$ as the dependent variable, and the independent variables are $\mathrm{X}_{1}, \mathrm{X}_{2}$, and $\mathrm{X}_{3}$ ". For the formula of the multiple linier regression equation used in this research as follows:

$$
Y=a+\beta_{1} X_{1}+\beta_{2} X_{2}+\beta_{3} X_{3}+\varepsilon
$$

Description:

$$
\begin{array}{lll}
\mathrm{Y} & : & \text { Customer Loyalty } \\
\mathrm{a} & : & \text { Constant } \\
\beta_{1} & : & \text { Coefficient of Trust } \\
\mathrm{X}_{1} & : & \text { Variable of Trust } \\
\beta_{2} & : & \text { Coefficient of Satisfaction } \\
\mathrm{X}_{2} & : & \text { Variable of Satisfaction } \\
\beta_{3} & : & \text { Coefficient of Commitment } \\
\mathrm{X}_{3} & : & \text { Variable of Commitment } \\
\mathrm{E} & : & \text { Error }
\end{array}
$$

\begin{tabular}{|c|c|c|c|c|c|c|}
\hline \multicolumn{7}{|c|}{ Coefficients $^{a}$} \\
\hline \multirow[b]{2}{*}{ Model } & & \multicolumn{2}{|c|}{ Unstandardized Coefficients } & \multirow{2}{*}{$\begin{array}{c}\begin{array}{c}\text { Standardized } \\
\text { Coefficients }\end{array} \\
\text { Beta } \\
\end{array}$} & \multirow[b]{2}{*}{$t$} & \multirow[b]{2}{*}{ Sig. } \\
\hline & & B & Std. Error & & & \\
\hline 1 & (Constant) & -.562 & .608 & & -.925 & .358 \\
\hline & Trust & 2.208 & .458 & .449 & 4.818 & .000 \\
\hline & Satisfaction & 1.183 & .232 & .466 & 5.097 & .000 \\
\hline & Commitment & .221 & .109 & .091 & 2.039 & .045 \\
\hline
\end{tabular}

Regarding hypothesis and the result of multiple linier regressions was also able to indicated whether the variables for trust, satisfaction and commitment partially have a significant influence to customer loyalty see Table 3 .

Table 3. Partial Test

With the Table 3, it's able to build a regression model as follow:

$$
Y=-0.562+2.208 X_{1}+1.183 X_{2}+0.221 X_{3}
$$

\section{Partially Test (t-test).}

"Partially test or $\mathrm{t}$ test basically shows how much influence each independent variable for trust, satisfaction and commitment partially on the dependent is customer loyalty". "Interpretation of results of t test, if the value of sig $<0.05$, then Ho is accepted and $\mathrm{H}_{1}$ is rejected'. 'In this case the independent variables partially no influence on the dependent variable or otherwise see Table 3."

\section{Simultaneously Test (F-test)}

"F test basically shows whether all the independent variables for trust, satisfaction and commitment are included in the model simultaneously influence - as the dependent variable is customer loyalty".
"Interpretation of results of $\mathrm{F}$ test, if the value of sig < 0.05 therefore Ho is accepted and $\mathrm{H}_{1}$ is rejected. In this case the independent variable simultaneously has no influence to the dependent variable". Based on Table 4 . its can be seen that the results of the value of $\mathrm{F}$ is 293.216 and sig $0.000<$ 0.05. it can be concluded that the variables for trust, satisfaction and commitment simultaneously has a significant influence to customer loyalty

Table 4. Simultaneously Test

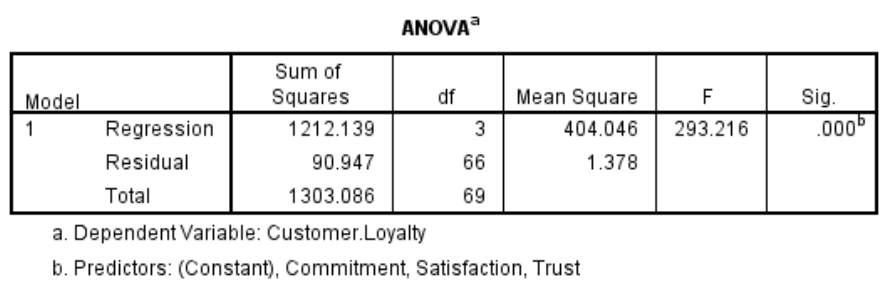

\section{CONCLUSION AND RECOMMENDATION}

\section{Conclusion}

Regarding to the results of the previous analysis and the conclusion as follows:

1. Variable of trust $\left(\mathrm{X}_{1}\right)$ partially significantly influence to the variable of customer loyalty $(\mathrm{Y})$

2. Variable of satisfaction $\left(\mathrm{X}_{2}\right)$ partially significantly influence to the variable of customer loyalty (Y)

3. Variable of commitment $\left(\mathrm{X}_{3}\right)$ partially significantly influence to the variable of customer loyalty (Y)

4. Variables of trust $\left(\mathrm{X}_{1}\right)$, satisfaction $\left(\mathrm{X}_{2}\right)$, variable commitment $\left(\mathrm{X}_{3}\right)$ are simultaneously significant effect to the variable of customer loyalty $(\mathrm{Y})$

\section{Recommendations.}

All independent variables turned out to be the result of discussions has the greatest influence on customer loyalty, trust variable $\left(\mathrm{X}_{1}\right)$ means that the variable of trust minimum must be maintained sustainably, while for the commitment variable coefficient value is very low, so that should be the training of human resources for employees

\section{REFERENCES}

[1] Ac Nelson. (2009). Majalah SWA No. 06/ XXV/ 19 Maret-1 April, 2009.

[2] Anderson, E. W. and Barton W. (1992). "The Use of Pledges to Build and Sustain Commitment in Distribution Channels. Journal of Marketing Research, 29 (February), 18-34

[3] Anderson, J.C., Narus, J.A., (1990). A Model of Distributor Firm and Manufacturer Firm Working Partnerships. Journal of Marketing, 91, 1:42-58

[4] Bricci, L., Fragata, A., Antunes, J. 2016. The Effects of Trust, Commitment and Satisfaction on Customer Loyalty in the Distributor Sector. Journal of Economics, Business and Management, 4 (2): 173-177.

[5] Cai, Z. and Wheale, P. (2004). Creating Sustainable Corporate Value: a Case Study of Stakeholder Relationship Management in China ${ }^{e e}$. Business and Society Review, 109(4): 507-547 
[6] Caruana, A. (2002). Service Loyalty: The Effects of Service Quality and the Mediating Role of Customer Satisfaction. European Journal of Marketing, 36 (7), 811-828

[7] Chidambaram, V, and Ramachandran, A, (2012), A Review of Customer Satisfaction towards Service Quality of Banking Sector. Social and Management Sciences, V2 (2), 71-79

[8] Churchill, G. A. and Suprenant, C (1982), An Investigation into the Determinants of Customer Satisfaction, Journal of Marketing Research, $19: 491-504$

[9] Davis-S., B., Mentzer, J.T. and Stank, T.P. (2008). Creating Consumer Durable Retailer Customer Loyalty through Order Fulfillment Service Operations ee $^{\text {e }}$ Journal of Operations Management, 26(6): 781-797.

[10] De Wulf, K., G. Odekerken-Schroder and D. Iacobucci (2001) Investments in Consumer

[11] Relationships: A Cross-country and Cross-industry Exploration, Journal of Marketing , 65(4), pp.33-50.

[12] Du Plessis, L. (2010). Customer Relationship Management and its Influence on Customer Loyalty at Liberty Life in South Africa . University of Johannesburg.

[13] Dwyer R. F., Schurr P. H. and Oh S. (1987). Developing BuyerSeller Relationships". Journal Marketing. 51:1-27.

[14] Evanschitzky, H. and Plassmann, H. (2006). Affective and Calculative Commitment as Antecedents of Customer Loyalty. American Marketing Association.

[15] Fornell, J.D. Michael, A. W. E., Jaesung. C and Bryant E. B. (1996) "The American Customer Satisfaction Index: Nature, Purpose and Findings," Journal of Marketing, 60: 7-18

[16] Ganiyu, R.A., I.I. Uche and A.O. Elizabeth . (2012). Is Customer Satisfaction an Indicator of Customer Loyalty? Australian Journal of Business and Management Research 2 (7): 14-20.

[17] Gefen, D. (2002). Customer Loyalty in e-Commerce. J. Assoc. Inform. Systems 3 27- 51.

[18] Ghozali, I.( 2009) . Aplikasi Analisis Multivariate Dengan Program SPSS, Edisi Keempat, Penerbit Universitas Diponegoro.

[19] Grönroos, C. (1997), "Value-Driven Relational Marketing: From Products to Resources and Competencies. Journal of Marketing Management 13 (4), 407-19

[20] Herscovitch, L. dan Meyer, J.P., (2002), Commitment to Organizational Change: Extension of a Three-Component Model. Journal of Applied Psychology.87, (3): 474-487.

[21] Homburg, C. and Rudolph, B. (2001). 'Customer Satisfaction in Industrial Markets: Dimensional and Multiple Role Issues. Journal of Business Research, Vol. 52, 15-33.

[22] Hui, E. C., \& Zheng, X. (2010). Measuring Customer Satisfaction of FM Service in Housing Sector: A Structural Equation Model Approach. Facilities, 28(5), 306-320.

[23] Ibrahim, H. and Najjar, F. (2008). Relationship Bonding Tactics, Personality Traits, Relationship Quality and Customer Loyalty: Behavioral Sequence in Retail Environment", ICFAI Journal of Services Marketing, vol. 6, no. 4, pp. 6 -37.

[24] Kaswara dan Santoso. (2008). Pengantar Teori Pengembangan Sumber Daya Manusia, Cetakan Pertama, Penerbit PT. Rineka Cipta, Jakarta

[25] Kheng, L, Mahamad, O, Ramayan, T and Mosahab, R. (2010). The Impact of Service Quality on Customer Satisfaction. A Study of Banks in Penang, Malaysia. International Journal of Marketing Studies, Vol, 2, No,2, November.

[26] Kim, E., and Tadisina, S., (2003). Customer's Initial Trust in EBusiness: How to Measure Customer's Initial Trust. Proceedings of Ninth Americas Conference on Information Systems, pp. 35-41.
[27] Kim, D. J., Ferrin, D. L., dan Rao, H. R., (2003a). Antecedents of Consumer Trust in B-to-C Electronic Commerce, Proceedings of Ninth Americas Conference on Information Systems, pp. 157-167.

[28] Kincaid, J. (2003). Customer Relationship Management: Getting it Right. London: Prentice Hall Professional.

[29] Kumar, D. P. and K.V. Raju. (2014). Perception of Unorganized Retailers Towards B2B Wholesalers-Metro and Best Price. ELK International Journal of Marketing, Volume 5 Issue 1, pp. 1-14.

[30] Kumar, K. S. (2012). Expectations and Perceptions of Passengers on Service Quality With Reference to Public Transport Undertakings. The IUP Journal of Operations Management, XI (3), 67-81

[31] Kuncoro. M. 2013. Metode Riset untuk Bisnis dan Ekonomi. Edisi 4. Penerbit Erlangga. PT. Gelora Aksara Pratama. Jakarta.

[32] Lau, M, Cheung, R, Lam, A, and Chu, Y (2013), Measuring Service Quality in the Banking Industry: a Hong Kong based Study. Contemporary Management Research. Vol, 9(3), pp-263283.

[33] Liniere, M, (2013). Factors that Contribute to the Decline of Customer Satisfaction in Banking. Thesis, PHD, Published, Walden University.

[34] Mayer, R.C., Davis, J. H., and Schoorman, F. D. (1995). An Integrative Model of Organizational Trust. Academy of Management Review. 30 (3): 709-734.

[35] Mayer J.P, Allen N.J, (1997). Commitment in the Workplace: Theory, Research, and Applications. Thousand Oaks, CA.: Sage Publishing, Inc.

[36] Morgan R. M. and Hunt S. D. (1994). The Commitment-Trust Theory of Relationship Marketing", J. Marketing. 58:20-38.

[37] Moorman, C., G. Zaltma, and R. Deshpande. (1992). Relationships between Providers and Users of Market Research: The Dynamics of Trust within and between Organizations. Journal of Marketing Research Vol. 29, No. 3, pp. 314-328

[38] Morgan, R.M. and Hunt, S.D. (1994), "The Commitment -Trust Theory of Relationship Marketing", Journal of Marketing, Vol. 58 No. 3, pp. $20-38$.

[39] Mukherjee, A., and Nath, P. (2003). A Model of Trust in Online Relationship Banking, International Journal of Bank Marketing , 21 (1): 5-15.

[40] Murphy, G. B. and Blessinger, A. A. (2003.) Perceptions of Noname Recognition Business to Consumer E-Commerce Trus Tworthiness: The Effectiveness of Potential Influence Tactics, Journal of High Technology Management Research, 14: 71-92

[41] Munusamy, J., Chelliah, S. and Mun, H., (2010). Service Quality Delivery and Its Impact on Customer Satisfaction in the Banking Sector in Malaysia. International Journal of Innovation, Management and Technology, Vol. 1, No. 4,pp. 398-404

[42] Nugroho, F. Y. (2011). Pengaruh Citra Merek dan Kepuasaan Pelanggan Terhadap Loyalitas Pelanggan. Jurnal Managemen Pemasaran, Vol. 2, No.2, h 90-102

[43] Oliver, R. (1980). "A Cognitive Model of the Antecedents and Consequences of Satisfaction Decisions" Journal of Marketing Research, Vol. 17, pp. 460-469

[44] Oliver, R.L.(1981). Measurement and Evaluation of Satisfaction Processes in Retailing, Journal of Retailing, 57 (3); 25-48

[45] Parasuraman, A., Zeithaml, V.A. and Berry, L.L. (1991), "Refinement and reassessment of the SERVQUAL scale", Journal of Retailing, Vol. 67 No. 4, pp. 420-50.

[46] Patricia M. D., P.M, J. M. Barry, and R. Abratt, (2007) "Trust Determinants and Outcomes in Global B2B Services". European Journal of Marketing. Vol. 41 Iss: 9/10, pp.1096 1116 
[47] Peppers, D. and Rogers, M. (2004). Managing Customer Relationships: a Strategic Framework, New York: John Wiley and Sons.

[48] Priyanto, D. 2013. Mandiri Belajar Analisis Data Dengan SPSS . Yogyakarta: Mediakom.

[49] Rangkuti, F.( 2003). Riset Pemasaran. Gramedia Pustaka Utama, Jakarta.

[50] Riegelsberger, J., Sasse, M. A., dan McCarthy, J. D., (2003). The Researcer's Dilemma: Evaluating Trust in Computer-Mediated Communication, International Journal of Human-Computer Studies , 58: 759-781.

[51] Rousseau, D.M., S.B. Sitkin, R.S. Burt, and C. Camerer.(1998). Not So Different After All: A Cross-Discipline View of Trust. Academy of Management Review 23:393-404.

[52] Santoso. S. 2010. Menguasai Statistik di Era Informasi SPSS Penerbit PT. Alex Media Komputindo. Kelompok Gramedia. Jakarta

[53] Santouridis, I., and Trivellas, P. (2010). Investigating the Impact of Service Quality and Customer Satisfaction on Customer Loyalty in Mobile Telephony in Greece. The TQM Journal, 22 (3), 330-343.

[54] San Martín, S., Gutiérrez, J. and Camarero, C. (2004) Trust as the Key to Relational Commitment, Journal of Relationship Marketing, 3 (1): 53-77

[55] Stone, M., Woodcock, N., and Machtynger, L. (2000). Customer Relationship Marketing: Get to Know Your Customers and Win their Loyalty (2nd eds.). Kogan Page Ltd. ISBN: 0-74942700-0.

[56] Schweizer, B. (2008). An Examination of Factors Leading to Abating Customer Loyalty Towards Magazine Subscriptions, Berlin: GRIN Verlag.

[57] Thurau, T. H and A.Klee. (1997), "The impact of Customer Satisfaction and Relationship Quality on Customer Retention: A Critical Reassessment and Model Development". Psychology and Marketing, 14 (8). 737-764.

[58] Tsoukatos, E and. Rand,G. (2006) "Path Analysis of Perceived Service Quality, Satisfaction and Loyalty in Greek Insurance", Managing Service Quality, Vol. 16 No. 5,pp. 501-19.

[59] Yau, O., Lee, J.S., Chow, R.P., Leo, Y.M., and Tse, A.C. (2000). Relationship Marketing the Chinese Way Business Horizons, January-February: 16-23.

[60] Yousafzai, S. Y., Pallister, J. G., dan Foxall, G. R. (2003). A Proposed Model of E-Trust for Electronic Banking, Technovation, 23: 847-860.

[61] Zeithaml, V. A., Berry, L. L. and Parasuraman, A. (1996). The Behavioral Consequences of Service Quality . Journal of Marketing Research, 60(2), 31-46. 